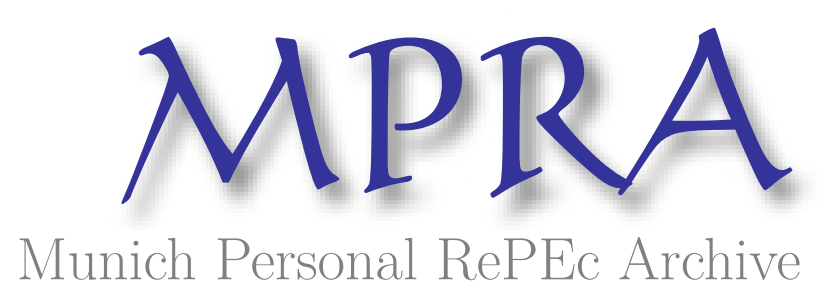

\title{
Nonlinearities in Wagner's law: Further evidence from South Africa
}

Phiri, Andrew

2 June 2016

Online at https://mpra.ub.uni-muenchen.de/71702/

MPRA Paper No. 71702, posted 04 Jun 2016 06:25 UTC 


\title{
Nonlinearities in Wagner's law: Further evidence from South Africa
}

\author{
A. Phiri \\ Department of Economics, Finance and Business Studies, CTI Potchefstroom Campus, \\ North West, South Africa
}

\begin{abstract}
Recently, it has being speculated that the linear relationship between government expenditure and economic growth may be misspecified. In our study, we contribute to the literature by investigating a nonlinear expenditure-growth relationship for South Africa by applying threshold cointegration analysis to six variations of Wagner's law. Indeed, our empirical analysis reveal a nonlinear relationship between the time series for four out of the six versions of Wagner's law thus providing strong evidence of existing nonlinearities for the case of South Africa. We further find uni-directional causality running from government spending to output productivity with positive increases in government expenditure leading to improved GDP levels hence lending support to the Keynesian hypothesis. And yet, we also find that negative deviations from the steady-state are eradicated slower than positive ones hence implying that increases in government spending would be offset by negative shocks to the macroeconomy over the long-run. This implies that excessive spending by South African government is not a panacea in overcoming the adverse effects of the recent global recession on the macroeconomy.
\end{abstract}

Keywords: Wagner's law; South Africa; nonlinear; cointegration; error correction model; causality.

JEL Classification Code: C22, E62, H50. 


\section{$1 \quad$ Introduction}

The investigation into the effects of government spending on economic growth is a fairly vibrant field of study which continues to draw increasing attention from academics and policymakers alike. Being complimentary to monetary policy in stabilizing the economy, government expenditure arguably represents the most important instrument of fiscal policy used in achieving this goal. In describing the benefits which government spending bears towards economic growth, Fallahi and Shoorkchali (2012) note that government spending establishes property rights, removes allocational distortions due to externalities, provides accessible schooling which contributes towards human capital development, enhances the investment environment through the provision of public goods as well as establishing law and order through regulations which contribute to economic growth by creating a safe environment. Conversely, some economists, like Odawara (2010), have argued that excessive government spending is detrimental to productivity growth since an overgrown government is often used inefficiently, crowds out investment, and results in higher interest payments and tax burdens. In light of this relationship between government spending and growth varying from one situation to another, it is imperative that researchers determine the extent to which government expenditure is either beneficial or detrimental towards economic growth in any particular economy.

Academically, there exist three competing hypotheses regarding the relationship between government expenditure and economic growth. The first of these is Wagner's hypothesis, which postulates causality running from economic growth to government expenditure. Ibok and Bassey (2013) state three reasons to support Wagner's hypothesis. (i) During an industrialization era, the administrative and regulatory functions of the state would substitute for private activity (ii) An increase in income would shift consumption preferences in favour of cultural and welfare services which can be provided through government expenditure (iii) Government spending can provide the necessary capital funds required to finance large-scale projects tailored to satisfy the technological needs of an industrialized society, where private sector lacks the capacity to do so. The second hypothesis is the Keynesian hypothesis which suggests causality running from government expenditure to economic growth. Under this later hypothesis, when government spending increases, production also increases, and this leads to an increase in aggregate demand which ultimately leads to an increase in economic growth (Odhiambo, 2015). And finally, there is the classical 
hypothesis which assumes no causality between government spending and economic growth. According to this view, government's fiscal policy does not have any effect on output growth, thus requiring government to avoid the risk of distorting the resource allocation through government intervention and allow the free markets to rein (Chipaumire et. al., 2014).

A substantial amount of empirical efforts have been dedicated towards examining the relationship between government expenditure and economic growth, which in all fairness can be deemed as being inconclusive in nature. This statement holds true both across different countries and for same country analysis, as is the case with South Africa. Take for instance, the studies of Ansari et. al. (1997), Ziramba (2008), Ogbonna (2009), Menyah and WoldeRufael (2012), Chipaumire et. al. (2014) and Odhiambo (2015) which have all analysed the relationship between government expenditure and economic growth for the case of South Africa and have obtained all sorts of conflicting empirical evidences. While Ogbonna (2009), Menyah and Wolde-Rufael (2012) and Odhiambo (2015) all find support for the Wagnerian hypothesis, on the other hand, Ansari et. al. (1997), Ziramba (2008) and Chipaumire et. al. (2014) reject Wagner's hypothesis for South African data with the study of Chipaumire et. al. (2014) even postulating a negative relationship between the two variables. Given the overall inconclusive nature of these reported results for the aforementioned case studies, the debate pertaining to the nature and the direction of causality between government spending and economic growth in South Africa still remains open to further deliberation.

Of recent, a growing number of academic works have challenged the notion of the relationship between government expenditure and economic growth being monotonic, thus advocating for a nonlinear relationship between the time series variables. Emerged empirical evidence supporting the notion of nonlinearities in the government spending-growth relationship has been documented for a number of economies inclusive of the United States (Grossman, 1988), Taiwan (Chen and Lee, 2005), South Korea, Malaysia, Singapore, Taiwan, Thailand (Chiou et. al., 2010), Poland (Gurgul et. al., 2011), Sri Lanka (Herath, 2012) and Iran (Mehrara and Keikha, 2012), just to name a few. The phenomenon of a nonlinear relationship between government spending and economic growth is reminiscent of Bird's (1972) ratchet hypothesis which depicts an inverted U-shaped relationship between the two variables. Theoretically, the notion of nonlinearities existing in the government spending-growth relationship bridges two previously opposing theories by hypothesizing on an initial positive relationship between the variables which turns negative after crossing some threshold or 
optimal point. Empirically, such nonlinearities have been captured through a number of nonlinear econometric models such as Hansen's (1999) threshold autoregressive (TAR) model, smooth transition regressions (STR) of Terasvirata (1994) as well as nonlinear causality models such as those presented in Diks and Panchenko (2006).

The purpose of our paper is to contribute to the literature by examining asymmetric cointegration relations between government expenditure and economic growth in South Africa, which is one of the largest economies in Sub Saharan Africa (SSA) and the only African member of the prominent group of emerging economies, the BRICS countries. To the best of our knowledge this paper is the first to do so for the case of South Africa and we consider this an important contribution to the literature since previous literature has not accounted for possible nonlinearities in the data. In our study we make use of the momentum threshold autoregressive and threshold error correction (MTAR-TEC) model as our empirical framework. We choose this model because, unlike other conventional econometric models, the MTAR-TEC facilitates for asymmetric cointegration modelling and asymmetric causality analysis all under a singular econometric framework. This makes the MTAR-TEC model more robust in capturing cointegration nonlinearities in comparison to other competing econometric models used so far in the literature.

Having laid the background to the study, the remainder of this article is structured as follows. The third section presents a brief review of the associated literature. The fourth section of the paper outlays the methodological framework for our empirical analysis. The fifth section presents the data and empirical results obtained from our estimations. The study is concluded in the sixth section of the paper in the form of policy implications and recommendations for the direction of future research.

\section{Government expenditure and economic growth in post-apartheid South} Africa

Following the democratic elections for South African in 1994, when the country transcended from it's previous apartheid regime to a more democratic state, government was faced with the remarkable challenge of restoring fiscal discipline in light of a growing demand for governmental expenditure resulting from political democratization (Calitz and Siebtris, 2003). With the end of the apartheid regime in 1994, the Government of National Unity adopted 
a Reconstruction and Development Programme (RDP) which, among many other goals, set numerical targets as fiscal guidelines used by policymakers. These targets included a budget deficit ratio of 2.5 percent of GDP and the achievement of a constant ratio of government revenue to GDP. During the early post-1994 period, government began to steadily increase investment expenditure on social and household infrastructure through the provision of housing, education, healthcare as well as through connecting households to electricity grids and water networks (Meyiwa et. al., 2004). In 1994 and 1995, the growth in South African government expenditure was 8.4 percent and 13.4 percent, respectively, which was a significant decrease from the previous 18.6 percent experienced in 1993. However, it is believed that this slower growth of government expenditures in the years immediately following the 1994 elections are not so much a reflection of a policy of fiscal constraint but are more of an attribute of high levels of government spending and the build-up of public debt inherited over fifty years under the Apartheid regime (Heintz, 2003). Economic growth, on the other hand, averaged 2.7 percent between 1994 and 1995, which is a favourable figure in comparison to the 0.6 percent average experienced between 1990 and 1993. Nevertheless, these economic growth rates were not as high as anticipated because of poor policy co-ordination and implementation methods used under the RDP programme.

In 1996, the government phased in a new macroeconomic and fiscal policy programme, Growth, Employment and Redistribution (GEAR) policy, which sought to improve previously disappointing economic growth rates and to also reduce the budget deficit through the restructuring of government at national, provincial and municipal levels. And yet, in 1996, growth in government expenditure briefly escalated to an average of 16.35 percent due to government increased spending on social investment and in particular, spending on education, health, welfare, housing and water services. Due to exercises of increased fiscal discipline applied from 1997 to 2000, government expenditure growth figures were then lowered to 9.28 percent, 7.2 percent, 5.1 percent and 6.3 percent, in these respective years. This period of decreased government spending was accompanied by lower economic growth performance with growth rates averaging 1.8 percent between 1997 and 1999. However, a less restrictive fiscal and counter-cyclical approach was then initiated in 2001, which saw government almost double its expenditure growth rates to 11.6 percent and increased these numbers to 12.8 percent, 12.9 percent, 11.6 percent and 12.8 percent in the subsequent years of 2002, 2003, 2004 and 2005, respectively. Notably, this increase in government spending was accompanied with improved economic growth figures of 3.5 percent over a four-year period of 2001-2004. 
It was in 2005, when the GEAR policy programme was phased out and ultimately replaced with Accelerated and Shared Growth Initiative for South Africa (ASGISA) programme, which envisioned halving unemployment to less than 14 percent and attaining economic growth rate averages of 6 percent between 2010 and 2014. Public infrastructure was identified as a binding constraint within the ASIGSA programme as the National Budget of 2006 envisaged that R415.8 billion would be invested in infrastructure over a three-year period (Calitz and Fourie, 2007). The country then experienced an all-time high post-apartheid economic growth rate of 5.6 percent as well as an all-time high post-apartheid budget surplus of 3.5 percent in 2006, which gave fiscal authorities leeway to further step-up government consumption to an average of 14.8 percent 2006 and 2008.

Following the subprime crisis of 2009, the South African economy fell into recession, averaging 1.5 percent GDP growth rate in 2009 but significantly picked up in the following two years, averaging 3.1 percent and 3.6 percent in 2010 and 2011, respectively. This quick recovery in economic growth rates after the recession was due to an 'economic shield' provided by government's budget surplus experienced between 2006 and 2007, as well as government's escalation of expenditure growth in 2008 and 2009, to record-high averages of 16.9 percent and 14.6 percent, respectively. In 2013, the Finance Ministry in conjunction with the Presidential Infrastructure Coordinating Commission (PICC), announced a planned R827 billion medium-term infrastructure investment expenditure framework. The PICC also set an infrastructure spending target of 10 percent of GDP which is to be met by the year 2030 . Moreover, in 2013 the Finance Ministry appointed the Davis Tax Committee to limit government expenditure and boost revenue collection through tax reforms in order to fund key policy objectives such as infrastructure development. Moreover, public infrastructure development has been identified as the main job creation driver under the National Development Plan (NDP) and the New Growth Path (NGP) macroeconomic policies and expenditure on infrastructure is projected to be R11 trillion over a 15 year period of 2015 to 2030. Nonetheless, growth in government expenditure lowered to an average of 8.4 percent between 2013 and 2015, and public investment infrastructure is current averaging 8 percent, which is below the 10 percent rate required in order for government to meet it's long-term infrastructure objectives. On the other hand, real GDP growth has been on downward trend from 2013 to 2015, averaging rates of 1.9 percent, 1.4 percent and 1.3 percent, respectively along these years. 


\section{$3 \quad$ Nonlinearities in Wagner's law - A review of the literature}

The notion of a nonlinear relationship between government expenditure and economic growth in the academic literature can be traced back as far as Bird (1972), who argued that the variation in output growth and fiscal policy would differ, depending on whether the economy is in an expansionary or contractionary phase of the business cycle. Since then, there has emerged a number of theoretical models which account for an inverted U-shaped relationship between public spending and economic growth, and collectively these models are referred to as the BARS curve in commemoration of Barro (1990), Armey (1995), Rahn and Fox (1996) and Scully (1995). In quantifying such nonlinearities, empirical researchers are dependent on three types of econometric frameworks. The first of these frameworks, is the threshold autoregressive (TAR) and this model has been used in the studies of Chen and Lee (2005) for Taiwan, Odarawa (2010) for the US, Australia, Canada, Japan and the UK, Abounoori and Nademi (2010) and Mehrara and Keikha (2012) for Iran, Christie (2012) for 135 developing and developed countries, Asimakopoulos and Karavias (2015) for 129 developing and developed countries and Hajamini and Falahi (2014) for 21 low-income and 11 low-middle income countries. Most of the aforementioned studies employ three measures of government size (i.e. total government expenditure, government consumption and government investment) which are run as threshold variables against economic growth. Needless-to-say, the results obtained in these studies for various countries are quite contradictory, not only in terms the value of the threshold estimates, but also in terms of the depicted regime switching behaviour. For instance, the works of Chen and Lee (2005), Odarawa (2010), Mehrara and Keikha (2012), Abounoori and Nademi (2010) and Asimakopoulos and Karavias (2015) all show that the size of government has a significantly positive relationship with economic growth below the spending threshold level and this relationship turns negative or insignificant above this threshold. On the other hand, the studies of Christie (2012) and Hajamini and Falahi (2014) report an insignificant relationship between the two variables below the threshold level whereas the relationship turns significantly negative above the threshold point. All-in-all, the evidence given by the former cluster of empirical works depicts an inverted U-shaped relationship between government size and economic growth as described by endogenous growth theory, whereby such evidence is lacking for the latter studies. 
The second type of empirical framework used in the literature is the smooth transition regression (STR) model and this model is consider superior to other competing nonlinear models such as the TAR and the Markov Switching (MS) models since it encompasses other nonlinear models. Moreover, the STR model is more theoretical appealing since it's transition from one regime state to another is smooth as opposed to being abrupt and the transition variable responsible for regime switching behaviour is endogenously determined. Studies which have used the STR model in the government spending-growth nexus include Fallahi and Shoorkchali (2012) for Greece, Chiou-Wei et.al. (2010) for South Korea, Malaysia, Singapore, Taiwan and Thailand, Mehdi and Shoorekchali (2012) for Italy and Su and Bui (2015) for ASEAN countries. Encouragingly, each of these studies establishes that government spending is responsible for regime switching behaviour amongst the time series variables. Furthermore, all countries investigated in this segment of reviewed literature, reveal that in the lower regime of the estimated STR models, government spending and economic growth are positively related whereas in the upper regime of the model the relationship is an inverse one. Once again, we treat this evidence as implying an inverted U-shaped relationship between government size and economic growth. The one exception is given for the case of Singapore whereby Chiou-Wei et. al. (2010) find converse regime switching behaviour for the country, thus implying a strict U-shaped relationship between the variables. Never-the-less the empirical evidence provided by these STR models provides more stringent evidence of an inverted U-shaped or a U-shaped relationship between government size and economic growth, since the described transition between the model regimes is smooth and is thus more theoretical valid.

The third type of nonlinear empirical framework found in the literature are studies which use nonlinear granger causality testing procedures in examining the government spending-growth relationship. In differing from the previously discussed 'nonlinear' literature, this cluster of studies take into account cointegration properties of the time series thus ruling out the possibility of obtaining spurious regression estimates. Furthermore, the cumulative evidence of a positive relationship between public spending and economic growth at low levels of expenditure, has been largely misinterpreted has been indicative of causality running from public spending to economic growth. This, in turn, creates the possibility of drawing misleading inferences and bogus policy implications from the empirical research. Nonetheless there has been a group of studies which use nonlinear causality models are belonging to this group are the works of Karagianni and Pempetzoglou (2009) for European Union countries, Grenade and Wright (2013) for Caribbean countries and Gurgul et. al. (2012) for Poland. 
Whilst Karagianni and Pempetzoglou (2009) and Gurgul et. al. respectively apply the modified nonlinear causality tests of Baek and Brook (1992) and that of Diks and Panchenko (2006), to individual countries, on the other hand, the study of Grenade and Wright (2013) applies the Baek and Brook (1992) tests within a panel framework. Overall, these nonlinear causality studies have failed to produce a deterministic causal relationship between government expenditure and economic growth for the various countries and panel groups under investigation thus rendering the subject matter open to further deliberation.

\section{$4 \quad$ Empirical Framework}

\subsection{Empirical specifications of Wagner's law}

For estimation purposes, Ziramba (2008), Karagianni and Pempetzoglou (2009) and Odhiambo (2015) identify six different empirical versions of Wagner's law existing in the literature. These are; i) the Peacock-Wiseman (1961) version, ii) the Gupta (1967) version, iii) the Goffman (1968) version, iv) the Pryor (1969) version, v) the Musgrave (1969) version `and vi) the Mann (1980) version. For the Peacock-Wiseman (1961) and Pryor (1969) versions of Wagner's law absolute values of time series are used in the regression specifications whereas for the remaining versions, at least one of the variables used is given in per capita terms. In denoting GDP as economic growth, Y as national income, GE as government expenditure, GC as government consumption, POP as total population and Log as a logarithmic transformation, we provide empirical estimation models for the six versions of Wagner's law in Table 1 below.

Table 1: Different functional forms of Wagner's law

\begin{tabular}{ccc}
\hline Equation & Functional form & Author \\
\hline I & $\log \mathrm{GE}_{\mathrm{t}}=\alpha+\beta \log \mathrm{GDP}_{\mathrm{t}}+\xi_{\mathrm{t} 1}$ & Peacock-Wiseman (1961) \\
II & $\log \left(\mathrm{GE}_{\mathrm{t}} / \mathrm{POP}_{\mathrm{t}}\right)=\alpha+\beta \log \left(\mathrm{GDP}_{\mathrm{t}} / \mathrm{POP}_{\mathrm{t}}\right)+\xi_{\mathrm{t}} \mathrm{s}$ & Gupta (1967) \\
III & $\log \mathrm{GE}_{\mathrm{t}}=\alpha+\beta \log \left(\mathrm{GDP}_{\mathrm{t}} / \mathrm{POP}_{\mathrm{t}}\right)+\xi_{\mathrm{t} 4}$ & Goffman (1968) \\
IV & $\log \mathrm{GC}_{\mathrm{t}}=\alpha+\beta \log \mathrm{Y}_{\mathrm{t}}+\xi_{\mathrm{t} 2}$ & Pryor (1969) \\
V & $\log \left(\mathrm{GE}_{\mathrm{t}} / \mathrm{Y}_{\mathrm{t}}\right)=\alpha+\beta \log \left(\mathrm{GDP}_{\mathrm{t}} / \mathrm{POP}_{\mathrm{t}}\right)+\xi_{\mathrm{t} 5}$ & Musgrave (1969) \\
VI & $\log \left(\mathrm{GE}_{\mathrm{t}} / \mathrm{GDP}_{\mathrm{t}}\right)=\alpha+\beta \log \left(\mathrm{GDP}_{\mathrm{t}}\right)+\xi_{\mathrm{t} t}$ & Mann (1980) \\
\hline
\end{tabular}

\subsection{MTAR-TEC modelling procedure}

As previously mentioned, most of the empirical literature investigating Wagner's hypothesis for South African data has relied on linear cointegration frameworks to reach various conclusions. However, Enders and Siklos (2001), have criticized the conventional 
linear cointegration framework on the premise of low power associated with the linear framework when the underlying time series is indeed asymmetric. To facilitate for asymmetric cointegration analysis between time series variables, Enders and Siklos (2001) propose the modelling the long-run cointegration error terms as threshold processes. In referring back to the long-run regressions equations (I) through (VI), as reported in Table 1, we follow in pursuit of Enders and Silkos (2001) by allowing the long-run residual deviations $\left(\xi_{\text {ti }}\right)$ to behave as threshold processes. In accordance with the authors, we propose two different asymmetric versions for modelling the error terms from the long-run regressions. The first is the TAR threshold cointegration model:

$\xi_{t}=\rho_{1} \xi_{t}\left(\xi_{t}<\tau\right)+\rho_{2} \xi_{t}\left(\xi_{t} \geq \tau\right)+v_{t}$

And the second is the MTAR threshold cointegration model:

$\xi_{t}=\rho_{1} \xi_{t}\left(\Delta \xi_{t}<\tau\right)+\rho_{2} \xi_{t}\left(\Delta \xi_{t} \geq \tau\right)+v_{t}$

Where $\Delta$ is a first difference operator and $\tau$ is the unknown threshold value which is estimated using a minimizing function as described in Hansen (2000). For both TAR and MTAR versions of the model, Enders and Silkos (2001) advice the testing of two hypothesis, the first being for cointegration effects and the second one being for asymmetric cointegration effects. The null hypothesis of no cointegration is given as $\mathrm{H}_{10}: \rho_{1}=\rho_{2}$ and is tested against the alternative of cointegration amongst the variables (i.e. $\mathrm{H}_{11}: \rho_{1} \neq \rho_{2}$ ). If the null hypothesis of no cointegration is rejected, then one can proceed to further test for the null hypothesis of linear cointegration (i.e. $\mathrm{H}_{20}: \rho_{1}=\rho_{2}=0$ ) against the alternative of asymmetric cointegration $\left(\mathrm{H}_{21}: \rho_{1} \neq \rho_{2} \neq 0\right)$. Once the null hypothesis of linear cointegration is rejected in favour of the alternative of threshold cointegration effects, then the short and long-run dynamics of equilibrium adjustment can be modelled through a corresponding threshold error correction (TEC) specifications which are specified as follows:

$$
\begin{aligned}
& \left(\begin{array}{l}
\Delta y_{t} \\
\Delta x_{t}
\end{array}\right)=\gamma_{1} \xi_{t-1}\left(\xi_{t}<\tau\right)+\sum_{i=1}^{p} \alpha \Delta y_{t-i}+\sum_{i=1}^{p} \beta \Delta x_{t-i}+\left\{\gamma_{2} \xi_{t-1}\left(\xi_{t} \geq \tau\right)+\sum_{i=1}^{p} \alpha \Delta y_{t-i}+\right. \\
& \left.\sum_{i=1}^{p} \beta \Delta x_{t-i}\right\}+\mu_{t}
\end{aligned}
$$




$$
\begin{aligned}
& \left(\begin{array}{l}
\Delta y_{t} \\
\Delta x_{t}
\end{array}\right)=\gamma_{1} \xi_{t-1}\left(\Delta \xi_{t}<\tau\right)+\sum_{i=1}^{p} \alpha \Delta y_{t-i}+\sum_{i=1}^{p} \beta \Delta x_{t-i}+\left\{\gamma_{2} \xi_{t-1}\left(\Delta \xi_{t} \geq \tau\right)+\right. \\
& \left.\sum_{i=1}^{p} \alpha \Delta y_{t-i}+\sum_{i=1}^{p} \beta \Delta x_{t-i}\right\}+\mu_{t}
\end{aligned}
$$

Regressions (3) and (4) are formal known as the TAR-TEC and MTAR-TEC regressions, respectively, hereby $\xi_{\mathrm{t}-1}$ denotes the equilibrium error term. Based on these threshold error correction (TEC) regressions, two main sets of hypothesis can be tested for. Firstly, the null hypothesis of no asymmetric error correction model (i.e. $\mathrm{H}_{30}: \gamma_{1} \neq \gamma_{2}$ ) can be tested against the alternative of threshold error correction model (i.e. $\mathrm{H}_{31}: \gamma_{1}=\gamma_{2}$ ). Secondly, the direction of causality amongst the time series can be evaluated by testing whether all values of $\Delta \mathrm{x}_{\mathrm{t}-\mathrm{i}}$ and $\Delta \mathrm{y}_{\mathrm{t}-\mathrm{i}}$ are significantly different from zero. In particular, the null hypothesis that $\mathrm{y}_{\mathrm{t}}$ does not granger cause $\mathrm{x}_{\mathrm{t}}$ is tested as $\mathrm{H}_{40}: \alpha_{\mathrm{i}}=0$ whereas the null hypothesis that $\mathrm{x}_{\mathrm{t}}$ does not granger cause $\mathrm{y}_{\mathrm{t}}$ is tested as $\mathrm{H}_{50}: \beta_{\mathrm{i}}=0$.

\section{$5 \quad$ Data and empirical analysis}

\subsection{Empirical data}

The time series data used in the study has been collected from two main sources, namely; the South African Reserve Bank (SARB) and the Federal Reserve Economic Data (FRED) online databases. The data consists of the gross domestic product at market prices (GDP), gross domestic product per capita (GDP.POP), gross national income (Y), national government total expenditure (GE), final government consumption (GC), ratio of government expenditure to GDP (GE.POP) and the total population (POP). The variables GDP, Y, GE and GC have been collected in millions of Rands whereas population is depicted in millions of people. Moreover, from this data, we are able to compute two other variables namely, i) the ratio of government expenditure to national income (GE.Y) as GE/Y, and ii) government expenditure per capita (GE.POP) as GE/POP. Also note that all data used in the study has being converted into natural logarithms for empirical purposes.

\subsection{Unit root tests}

As a preliminary step to our empirical analysis, we perform unit root tests on the time series. For this purpose, we rely on three type of unit root tests, namely, the Augment Dickey- 
Fuller (ADF), Phillips-Perron (PP) and Elliot, Rothenberg and Stock (ERS) unit root tests. Whilst the PP unit root test is merely a non-parametric modification to the ADF-statistic to account for autocorrelation and heteroscedasticity that may be present in the data generating process (DGP) of a time series whereas, the ERS unit root tests uses a modified DF-statistic based on generalized least squares (GLS) de-trending rationale and exhibits improved power at near stationary unit root autoregressive coefficients in a small sample size. We perform each of the tests with a drift and with a trend, and we report the results in Table 2 below. As can be observed, the null hypothesis of unit roots cannot be rejected for all the time series in their levels, hence ruling out the possibility of the time series variables being stationary $\mathrm{I}(0)$ processes. However, when the time series are converted into their first differences, the unit root test results provide overriding evidence for the rejection of the unit root hypothesis hence rendering each of the time series as first difference stationary $\mathrm{I}(1)$ processes.

Table 2: Unit root test results

\begin{tabular}{|c|c|c|c|c|c|}
\hline \multirow[t]{2}{*}{ time series } & \multirow[t]{2}{*}{ test statistic } & \multicolumn{2}{|c|}{ levels } & \multicolumn{2}{|c|}{ first differences } \\
\hline & & drift & trend & drift & trend \\
\hline \multirow[t]{3}{*}{ GE } & $\mathrm{ADF}$ & $-3.40 * *$ & -2.92 & $-5.16 * * *$ & $-5.49 * * *$ \\
\hline & $\mathrm{PP}$ & -2.81 & -2.32 & $-9.76 * * *$ & $-10.72 * * *$ \\
\hline & ERS & -2.53 & -1.03 & 0.72 & -2.52 \\
\hline \multirow[t]{3}{*}{ GDP } & $\mathrm{ADF}$ & -1.48 & -2.07 & $-5.72 * * *$ & $-5.93 * * *$ \\
\hline & PP & -1.61 & -1.75 & $-5.76 * * *$ & $-5.84 * * *$ \\
\hline & ERS & 0.46 & -1.27 & $-3.80 * * *$ & $-4.22 * * *$ \\
\hline \multirow[t]{3}{*}{ GE.POP } & $\mathrm{ADF}$ & -0.84 & -1.51 & $-6.16 * * *$ & $-6.16 * * *$ \\
\hline & PP & -0.81 & -2.13 & $-10.18 * * *$ & $-10.13 * * *$ \\
\hline & ERS & 0.08 & -1.47 & $-3.30 * *$ & $-3.66 * * *$ \\
\hline \multirow[t]{3}{*}{ GDP.POP } & $\mathrm{ADF}$ & $-2.64 *$ & -2.51 & $-6.39 * * *$ & $-6.56 * * *$ \\
\hline & PP & -2.42 & -2.38 & $-8.78 * * *$ & $-8.89 * * *$ \\
\hline & ERS & -0.33 & -1.56 & $-3.25 * * *$ & $-3.24 * *$ \\
\hline \multirow[t]{3}{*}{ GC } & $\mathrm{ADF}$ & -2.08 & $-3.35^{*}$ & $-6.11 * * *$ & $-6.05 * * *$ \\
\hline & PP & -1.81 & -2.89 & $-6.13 * * *$ & $-6.06 * * *$ \\
\hline & KPSS & -0.87 & $-3.02 *$ & $-4.29 * * *$ & $-4.16^{* * *}$ \\
\hline \multirow[t]{3}{*}{$\mathrm{Y}$} & $\mathrm{ADF}$ & -1.68 & -2.07 & $-5.21 * * *$ & $-5.39 * * *$ \\
\hline & $\mathrm{PP}$ & -1.56 & -1.73 & $-6.25 * * *$ & $-6.39 * * *$ \\
\hline & ERS & 0.36 & -1.44 & $-3.08 * * *$ & $-3.68 * * *$ \\
\hline \multirow[t]{3}{*}{ GE.Y } & $\mathrm{ADF}$ & -2.47 & 0.24 & $-3.75 * * *$ & $-4.44 * * *$ \\
\hline & PP & -2.43 & 0.55 & $-4.98 * * *$ & $-5.74 * * *$ \\
\hline & ERS & -0.14 & -0.87 & -1.46 & -1.78 \\
\hline \multirow[t]{3}{*}{ GE.GDP } & $\mathrm{ADF}$ & -0.84 & -1.51 & $-6.16^{* * *}$ & $-6.12 * * *$ \\
\hline & PP & -0.81 & -2.13 & $-10.18 * * *$ & $-10.13 * * *$ \\
\hline & ERS & -0.08 & -1.47 & $-3.30 * * *$ & $-3.66 * * *$ \\
\hline
\end{tabular}


and -2.58 , respectively. For the ADF unit root test with a trend, the $1 \%, 5 \%$ and $10 \%$ critical values are $-4.04,-3.45$ and -3.15 , respectively. For the PP unit root test with a drift, the $1 \%, 5 \%$ and $10 \%$ critical values are $-3.55,-2.92$ and -2.60 , respectively. For the PP unit root test with a trend, the $1 \%, 5 \%$ and $10 \%$ critical values are $-4.13,-3.49$ and -3.18 , respectively. For the ERS unit root test with a drift, the $1 \%, 5 \%$ and $10 \%$ critical values are $-2.61,-1.95$ and -1.62 , respectively. For the ERS unit root test with a trend, the $1 \%, 5 \%$ and $10 \%$ critical values are $3.58,-3.03$ and -2.74 , respectively.

\subsection{Threshold cointegration tests}

Having, concluded that each of the time series exhibits I(1) behaviour, we proceed to model TAR and MTAR models for the six versions of Wagner's law i.e. Equations I to VI in Table 3. That gives us a total of 12 estimation equations. As a preliminary step, we test for three hypothesis pertaining to cointegration and error-correction effects from the errors obtained from estimates of the 12 threshold regression equations. To recall, the first hypothesis $\left(\mathrm{H}_{01}\right)$ tests for the null of no cointegration effects; the second hypothesis $\left(\mathrm{H}_{02}\right)$ tests the null hypothesis of linear cointegration effects; and the third hypothesis $\left(\mathrm{H}_{03}\right)$ tests the null of no threshold error correction effects. The results pertaining to testing of these hypotheses are reported in Table 4. As can be observed from Table 2, none of the TAR regressions manages to reject all three null hypotheses thus rendering these regressions as inappropriate for estimation purposes. However, we find that the MTAR regressions for Wagner equations I, II, IV and VI successfully reject all three null hypotheses thus implying that these four MTAR models can be used to model long-run threshold cointegration effects and corresponding threshold error correction (TEC) effects. We proceed to do so in the following sub-section.

Table 3: Threshold cointegration test results

\begin{tabular}{ccccccc}
\hline & \multicolumn{3}{c}{ TAR model } & \multicolumn{3}{c}{ MTAR model } \\
\hline Equation & $\mathrm{H}_{10}$ & $\mathrm{H}_{20}$ & $\mathrm{H}_{30}$ & $\mathrm{H}_{10}$ & $\mathrm{H}_{20}$ & $\mathrm{H}_{30}$ \\
I & 2.47 & 1.96 & 4.19 & 6.17 & 8.96 & 6.39 \\
& $(0.09)^{*}$ & $(0.17)$ & $(0.04)^{* *}$ & $(0.00)^{* * *}$ & $(0.00)^{* * *}$ & $(0.02)^{* *}$ \\
II & 4.05 & 2.59 & 0.21 & 8.52 & 10.52 & 3.08 \\
& $(0.02)^{*}$ & $(0.11)$ & $(0.65)$ & $(0.00)^{* * *}$ & $(0.00)^{* * *}$ & $(0.08)^{*}$ \\
III & 2.47 & 1.96 & 0.43 & 1.44 & 0.01 & 4.19 \\
& $(0.09)^{*}$ & $(0.17)$ & $(0.52)$ & $(0.25)$ & $(0.91)$ & $(0.04)^{* *}$ \\
IV & 55.72 & 3.83 & 0.30 & 55.47 & 3.66 & 2.50 \\
& $(0.00)^{* * *}$ & $(0.05)^{*}$ & $(0.59)$ & $(0.00)^{* * *}$ & $(0.06)^{*}$ & $(0.10)^{*}$ \\
V & 2.93 & 2.87 & 0.24 & 2.00 & 1.12 & 0.21 \\
& $(0.06)^{*}$ & $(0.09)^{*}$ & $(0.63)$ & $(0.15)$ & $(0.29)$ & $(0.65)$
\end{tabular}




\begin{tabular}{|c|c|c|c|c|c|c|}
\hline \multirow[t]{2}{*}{ VI } & 4.07 & 2.57 & 0.42 & 8.42 & 10.44 & 10.65 \\
\hline & $(0.02)^{*}$ & $(0.11)$ & $(0.52)$ & $(0.00) * * *$ & $(0.00)^{* * *}$ & $(0.00)^{* * *}$ \\
\hline
\end{tabular}

Note: “***”, “**”, “*”, respectively denote the 1 percent, 5 percent and 10 percent significance levels. The p-values are reported in ().

\subsection{Threshold cointegration and error correction model estimates}

Having verified threshold cointegration and error correction effects for four out of the six Wagner's functional equations, we proceed to estimate the MTAR-TEC specifications for these functional equations and report the results in Table 4 below.

Table 4: MTAR-TEC estimates

\begin{tabular}{|c|c|c|c|c|c|c|c|c|}
\hline & \multicolumn{2}{|c|}{ Equation I } & \multicolumn{2}{|c|}{ Equation II } & \multicolumn{2}{|c|}{ Equation IV } & \multicolumn{2}{|c|}{ Equation VI } \\
\hline & ge & gdp & ge.pop & gdp.pop & gc & $\mathrm{Y}$ & ge.gdp & Gdp \\
\hline \multirow[t]{2}{*}{$\alpha_{0}$} & 66.89 & & 7.11 & & 0.01 & & 7.11 & \\
\hline & $(0.00)^{* * *}$ & & $(0.00)^{* * *}$ & & $(0.99)$ & & $(0.00)^{* * *}$ & \\
\hline \multirow[t]{2}{*}{$\alpha_{1}$} & 0.04 & & 4.58 & & 0.79 & & 0.46 & \\
\hline & $(0.00)^{* * *}$ & & $(0.00)^{* * *}$ & & $(0.00)^{* * *}$ & & $(0.00)^{* * *}$ & \\
\hline $\mathrm{T}$ & 4.30 & & 81.71 & & & & & \\
\hline \multirow[t]{2}{*}{$\rho_{1}$} & -0.51 & & -0.16 & & -0.73 & & -0.51 & \\
\hline & $(0.00)^{* * *}$ & & $(0.02)^{*}$ & & $(0.00)^{* * *}$ & & $(0.00)^{* * *}$ & \\
\hline \multirow[t]{2}{*}{$\rho_{2}$} & -0.01 & & -0.07 & & -1.09 & & -0.04 & \\
\hline & $(0.91)$ & & $(0.77)$ & & $(0.00)^{* * * *}$ & & $(0.58)$ & \\
\hline \multirow[t]{2}{*}{$\Delta y_{t-k}^{+}$} & 0.47 & -3.99 & 0.31 & 0.01 & 0.39 & -0.12 & 0.22 & 0.29 \\
\hline & $(0.03)^{* *}$ & $(0.26)$ & $(0.16)$ & $(0.76)$ & $(0.06)^{*}$ & $(0.64)$ & $(0.85)$ & $(0.17)$ \\
\hline \multirow[t]{2}{*}{$\Delta y_{t-k}^{-}$} & -0.29 & 3.39 & 0.15 & 0.01 & -0.07 & -0.16 & 0.21 & 0.19 \\
\hline & $(0.42)$ & $(0.57)$ & $(0.61)$ & $(0.79)$ & $(0.82)$ & $(0.69)$ & $(0.89)$ & $(0.50)$ \\
\hline \multirow[t]{2}{*}{$\Delta x_{t-k}^{+}$} & 0.03 & 7.30 & 8.15 & 0.93 & -0.16 & 0.32 & 4.23 & 1.08 \\
\hline & $(0.28)$ & $(0.09)^{*}$ & $(0.20)$ & $(0.81)$ & $(0.21)$ & $(0.07)^{*}$ & $(0.23)$ & $(0.08) *$ \\
\hline \multirow[t]{2}{*}{$\Delta x_{t-k}^{-}$} & 0.01 & -3.68 & -2.01 & -7.00 & -0.11 & -0.78 & -6.34 & -0.83 \\
\hline & $(0.83)$ & $(0.00)^{* * *}$ & $(0.54)$ & $(0.06)^{* *}$ & $(0.74)$ & $(0.09)^{*}$ & $(0.00)^{* * * *}$ & $(0.60)$ \\
\hline \multirow[t]{2}{*}{$\lambda^{+} \xi_{t-1}^{+}$} & 0.02 & 7.55 & -0.02 & 0.01 & -0.49 & -0.14 & 0.01 & 0.68 \\
\hline & $(0.33)$ & $(0.21)$ & $(0.76)$ & $(0.13)$ & $(0.00)^{* * *}$ & $(0.34)$ & $(0.76)$ & $(0.01)^{* *}$ \\
\hline \multirow[t]{2}{*}{$\lambda^{-} \xi_{t-1}^{-}$} & -0.01 & -3.17 & -0.06 & 0.01 & 0.09 & 0.42 & -0.06 & -0.21 \\
\hline & $(0.78)$ & $(0.05)^{*}$ & $(0.10)^{*}$ & $(0.21)$ & $(0.71)$ & $(0.22)$ & $(0.07)^{*}$ & $(0.18)$ \\
\hline $\mathrm{R}^{2}$ & 0.31 & 0.46 & 0.39 & 0.19 & 0.84 & 0.26 & 0.50 & 0.21 \\
\hline \multirow[t]{2}{*}{ Dw } & 2.11 & 2.20 & 2.18 & 2.23 & 2.02 & 2.41 & 2.16 & 2.16 \\
\hline & $(0.96)$ & $(0.60)$ & $(0.73)$ & $(0.55)$ & $(0.95)$ & $(0.20)$ & $(0.78)$ & $(0.73)$ \\
\hline
\end{tabular}

As can be observed from Table 4, all estimated regressions produce positive long-run regression coefficients (i.e. $\alpha_{1}$ ), with these long-run elasticities ranging from 0.04 to 4.58 . This 
result is not only coherent with Wagner's original proposition, but also joins a host of other empirical works which find a similar positive relationship for South African data (i.e. Ansari et. al. (1997), Ziramba (2008), Ogbonna (2009), Menyah and Wolde-Rufael (2012) and Odhiambo (2015)). In focusing on the coefficient estimates of our threshold error correction terms (i.e. $\mathrm{p}_{1}, \mathrm{p}_{2}$ ), we find that the coefficient estimates above the threshold are significantly larger than the estimates below the threshold (i.e. $\mathrm{p}_{1}<\mathrm{p}_{2}$ ) for equations I, II and VI. This implies that positive deviations of the time series variables from their long-run steady-state equilibrium are eradicated at a quicker rate than negative deviations for equilibrium relationships between i) government expenditure and GDP ii) per capita government expenditure and per capita GDP iii) government consumption component and national income, and iv) ratio between government expenditure. The opposite holds true for equation VI, from which we observe that negative deviations from the long-run equilibrium are eradicated quicker than positive deviations (i.e. $\mathrm{p}_{1}>\mathrm{p}_{2}$ ) between the ratio of government expenditure to GDP and GDP.

Concerning error correction behaviour, we find that at least one significantly negative error correction term for each of the estimated MTAR-TEC models, thus signifying equilibrium reverting behaviour of the variables in the face of external shocks or disturbances to the system over the steady-state. As can be also seen from Table 4, the estimates of the lagged differences of the time series are, for the most part of it, insignificant thus implying the absence of equilibrium dynamic behaviour of the variables over the short-run. As can also be observed in Table 4 , the estimates of the error correction terms vary from -0.064 to -0.316 , a result which implies that between 6.4 percent and 31.6 percent of disequilibrium from the steady-state are corrected annually. However, we note inconsistencies in the short-run equilibrium dynamics as a majority of the differenced lagged variables turn out to be insignificant thus ruling out the possibility of any consistent short-run behaviour amongst the time series.

Lastly, we perform, granger causality tests for each of the estimated MTAR-TEC model regressions and we report the results in Table 5 below. As can be observed, the F-statistics testing the null hypothesis of the dependent variable granger causing the dependent variable exceeds the tabulated critical values at all levels of significance for equations I, II and VI), hence reject the null hypothesis. Conversely, F-statistic testing the null of the dependent variable granger causing the independent variable is lower than the critical values at all levels of significance for equations I, II and VI whereas the test statistic exceeds the critical value for 
equation IV. Collectively, these results imply granger causality running from i) government expenditure to GDP, ii) per capita GDP to per capita GDP, iii) national income to government consumption, and iv) share of government expenditure in GDP to GDP. Notably, these results are in coherence with those presented in Ogbonna (2009), Menyah and Wolde-Rufael (2012) and Odhiambo (2015), who presented similar evidence for the South African economy albeit using different econometric techniques.

Table 5: Granger causality tests

\begin{tabular}{|c|c|c|c|c|c|}
\hline equation & $\begin{array}{l}\text { dependent } \\
\text { variable }(y)\end{array}$ & $\begin{array}{l}\text { independent } \\
\text { variable (x) }\end{array}$ & $\begin{array}{l}\text { x granger } \\
\text { causes y }\end{array}$ & $\begin{array}{l}\text { y granger } \\
\text { causes } \mathrm{x}\end{array}$ & Decision \\
\hline & & & F-stat & F-stat & \\
\hline I & ge & gdp & $\begin{array}{c}7.79 \\
(0.00)^{* * *}\end{array}$ & $\begin{array}{c}0.67 \\
(0.52)\end{array}$ & ge $\rightarrow$ gdp \\
\hline II & ge.pop & gdp.pop & $\begin{array}{c}10.67 \\
(0.00)^{* * *}\end{array}$ & $\begin{array}{c}1.06 \\
(0.35)\end{array}$ & ge.pop $\rightarrow$ gdp.pop \\
\hline IV & $\mathrm{gc}$ & $\mathrm{Y}$ & $\begin{array}{c}1.58 \\
(0.22)\end{array}$ & $\begin{array}{c}8.76 \\
(0.00)^{* * *}\end{array}$ & $\mathrm{Y} \rightarrow \mathrm{gc}$ \\
\hline VI & ge.gdp & gdp & $\begin{array}{c}8.76 \\
(0.00)^{* * *}\end{array}$ & $\begin{array}{c}1.58 \\
(0.22)\end{array}$ & ge.gdp $\rightarrow$ gdp \\
\hline
\end{tabular}

\section{Conclusion}

Primary motivated by the recent surge of empirical research which has hypothesized on a nonlinear relationship between government expenditure and economic growth, our study sought to contribute to the literature by investigating nonlinearities in Wagner's law for the case of South Africa, one of the largest economies in the SSA region. To this end, we apply MTAR and TEC econometric techniques to model the asymmetric cointegration relationship for six functional forms of Wagner's law. Indeed our empirical results indicate a nonlinear relationship between government expenditure and output productivity hence insinuating that previously used linearly specification may be misspecified. Nonetheless, in similarity to a majority of previous case studies conducted for the South Africa economy, we find a positive long-run relationship between different proxies of government spending and output productivity as well as finding causality running from government spending to GDP levels. 
These results generally lay support for the Keynesian hypothesis which contends for government spending causing an improvement economic growth within a country and ultimately our results render government spending as an exogenous factor of economic growth in South Africa in terms of both levels and per capita measures. We further deem these results as being plausible since historical data has shown that government spending in South Africa has significantly increased following an economic crisis or pandemic to the economy, and this, more often than not, leads to periodic increases in economic growth rates. For instance, during the recent global recession period of 2009 , government spending increased immensely and this was accompanied by improvements in output productivity in the following few years afterwards. Notably, this is in compliance with our empirical finding of government expenditure granger causing economic growth. However, one exception to our results concerns the correlation between government consumption component and national income (GNI) in which we find causal effects running from government consumption to income received by South African residents. This may be the case, when considering that taxation incurred by South African residents maybe a primary source of government revenue income thus inferring causality running from GNI to government consumption items. Nonetheless, we conclude on overriding evidence of total government expenditure, inclusive of both spending and investment items, leading to economic growth thus magnifying the role which government spending activities exerts on future economic development and prosperity in the country.

Based on the analysis of our estimated threshold equilibrium errors, we also find that in the event of a shock to the variables, negative deviations are slower to be eradicated in comparison to positive deviations. This latter result implies that negative developments in the economic variables have longer lasting effects than positive ones do. This is demonstrable by the recent global financial crisis of 2007 and resulting global depression of 2009, which is largely responsible for the declining growth in GDP experienced over the last couple of years. And even though government spending has been extensively applied to circumvent the effects of the global recession, the negative shocks still appear to be outweighing the positive shocks as economic growth is currently on a downward trend. This observation is important, since it implies that current government spending in isolation may not be enough to overcome the adverse effects of the global recession on the South African macroeconomy. Another factor worth taking note of is that increased government spending activities tend to be accompanied by larger government debt and budget deficits which has recently been shown to crowd out investment in South Africa (Biza et. al. 2015). It should thus be a goal of government to firstly 
find alternative forms of financing besides that of incurring more government debt and risking the possibility of overwhelming interest payments on such debt. One plausible avenue for future financing of government spending activities is through increasing reliance on indirect taxation and putting less emphasis on direct taxes. Government also needs to be also concerned with devising policies which improve coordination between fiscal and monetary policies with the common agenda of increasing economic growth. We therefore recommend two important directions for future research into the debate. Firstly, future research should be directed towards examining the effects of fiscal and monetary policies on the South African macroeconomy with the intention of identifying optimal policies which would stabilize macroeconomic volatilities. Secondly, future research should be done to access the trade-off effects of direct and indirect taxes, as sources of government revenue, on economic growth.

\section{REFERENCES}

Abounoori E. and Nademi Y. (2010), "Government size and economic growth in Iran", International Journal of Business and Development Studies, 2(1), 95-108.

Armey D. (1995), "The freedom revolution: Why big government failed, why freedom works, and how we will rebuild America", Washington, DC: Regnery Publishing.

Ansari M., Gordon D. and Akuamoah C. (1997), "Keynes versus Wagner: Public expenditure and national income for three African countries", Applied Economics, 29, 543-550.

Asimakopoulos S. and Karavias Y. (2015), "The impact of government size on economic growth: A threshold analysis", Granger Centre Discussion Paper No. 15-02, June.

Baek E. and Brook W. (1992), “A general test for non-linear granger causality: Bivariate model”, Working Paper, Iowa State University and University of Wisconsin, Madison.

Barro R. (1990), “Government spending in a simple model of endogenous growth”, Journal of Political Economy, 98, 103-126.

Bird R. (1972), “The displacement effect”, Finanzarchiv, 30(3), 454-463. 
Biza R., Kapingura F. and Tsegaye A. (2015), "Do budget deficits crowd out private investment? An analysis of the South African economy", International Journal of Economic Policy in Emerging Economies, 8(1), 52-76.

Calitz E. and Siebtris F. (2003), "Fiscal policy in the 1990s", South African Journal of Economic History, 18, 50-75.

Calitz E. and Fourie J. (2007), "Infrastructure in South Africa: Who is to finance and who is to pay?", Stellenbosch Working Papers No. 15/07, April.

Chen S. and Lee C. (2005), "Government size and economic growth in Taiwan: A threshold regression approach", Journal of Policy Modelling, 27, 1051-1066.

Chiou S., Zhu Z. and Kuo Y. (2010), "Government size and economic growth: A application of the smooth transition regression model”, Applied Economic Letters, 17, 1405-1415.

Chipaumire G., Ngirande H., Method M. and Ruswa Y. (2014), "The impact of government spending on economic growth: Case South Africa", Mediterranean Journal of Social Sciences, 5(1), 109-118.

Christie T. (2012), "The effect of government spending on economic growth: Testing the nonlinear hypothesis", Bulletin of Economic Research, 66(2), 183-204.

Diks C. and Panchenko V. (2006), "A new statistic and practical guides for nonparametric granger causality testing”, Journal of Economic Dynamics and Control, 30, 1647-1669.

Enders W. and Granger C. (1998), "Unit root tests and asymmetric adjustment with an example using the term structure of interest rates", Journal of Business and Economic Statistics, 16, 304-311.

Enders W. and Siklos P. (2001), "Cointegration and threshold adjustment", Journal of Business and Economic Statistics, 19(2), 166-176. 
Fallahi F. and Shoorkchali J (2012), "Government size and economic growth in Greece: A smooth transition approach", retrieved from http://www.econmodels.com/upload7282/6a6ba1cf08f52069e825ac968dec3b06.pdf

Goffman I. (1968), “On the empirical testing of Wagner's law: A technical note”, Public Finance, 23(3), 359-364.

Grossman P. (1988), “Government and economic growth: a non-linear relationship", Public Choice, 56, 193-200.

Gupta S. (1967), "Public expenditure and economic growth: A time series analysis", Public Finance, 22, 423-461.

Gurgul H., Lach L. and Mestel R. (2012), “The relationship between budgetary expenditure and economic growth in Poland", Central European Journal of Research, 20(1), 161-182.

Hajamini M. and Falahi M. (2014), “The nonlinear impact of government consumption expenditure on economic growth: Evidence from low and low-middle income countries", Cogent Economics and Finance, 2, 1-15.

Hansen B. (2000), "Sample splitting and threshold estimation", Econometrica, 68(3), 575-604.

Herath S. (2012), "Size of government and economic growth: A nonlinear analysis", Economic Annals, 57(194), 7-30.

Heintz J. (2003), "Out of gear? Economic policy and performance in post-apartheid South Africa”, PERI Research Brief 2003-1, January.

Horton M. (2005), "Role of fiscal policy in stabilization and poverty alleviation”, In: M. Nowak and L. Ricci (eds.), Post-Apartheid South Africa. The first ten years, Washington, IMF.

Ibok O. and Bassey N. (2013), “Wagner's law revisited: The case of Nigerian Agricultural sector (1961-2012)", International Journal of Food and Agriculture Economics, 2(3), 19-32. 
Karagianni S. and Pempetzoglou M. (2009), "Evidence for non-linear causality between public spending and income in the European Union countries", The Journal of Applied Business Research, 25(1), 69-82.

Mann A. (1980), “Wagner's law: An econometric test for Mexico 1926-1976”, National Tax Journal, 33, 189-201.

Mehdi S. and Shoorekchali M. (2012), "The impact of government size on economic growth: A case study for Italy", Australian Journal of Basic and Applied Sciences, 6(9), 616-621.

Mehrara M. and Keikha A. (2012), "Government size and economic growth in Iran", International Journal of Economic Research, 3(2), 5-60.

Menyah K. and Wolde-Rufael Y. (2012), "Wagner's law revisited: A note from South Africa”, South African Journal of Economics, 80(2), 200-208.

Meyiwa T., Nkondo M., Chitiga-Mabugu M., Sithole M. and Nyamnjoh F. (2014), "State of the nation: South Africa 1994-2014 A twenty year review of freedom and policy", Pretoria: HSCR Press.

Musgrave R. (1969), “Fiscal systems”, New Haven: Yale University Press.

Odawara R. (2010), “A threshold approach to measuring the impact of government size on economic growth", Department of Economics, The George Washington University, November.

Odihambo N. (2015), "Government spending and economic growth in South Africa", Atlantic Economic Journal, 43(3), 393-406.

Ogbonna B. (2009), “Testing Wagner's law of government size for South Africa”, Journal of Research in National Development, 7(2), 1596-8308.

Peacock A. and Wiseman J. (1961), "The growth of public expenditure in the United Kingdom", Princeton: Princeton University Press. 
Pryor F. (1969), “Public expenditures in communist and capitalist nations”, London: George Allen and Unwin.

Rahn R. and Fox H. (1996), "What is the optimal of government", Vernon K. Krieble Foundation.

Ram R. (1986), “Government size and economic growth: A new framework and some evidence from cross-sectional and time-series data”, American Economic Review, 76, 191-203.

Scully G. (1995), “The growth tax in the United States”, Public Choices, 85, 71-80.

Su T. and Bui M. (2015), "The threshold of government size and economic growth for ASEAN countries: An analysis of the smooth transition regression model", Southeast Asian Journal of Economics, 3(1), 103-124.

Terasvirta T. (1994), "Specification, estimation and evaluation of smooth transition autoregressive models", Journal of the American Statistical Association, 89, 208-218.

Visser W. (2004), “Shifting RDP into gear. The ANC government's dilemma in providing an equitable system of social security for the 'new' South Africa", Paper presented at the $40^{\text {th }}$ ITH Linzer Konferenz, Austria, September.

Ziramba E. (2008), “Wagner's law: An econometric test for South Africa, 1960-2006”, South African Journal of Economics, 76(4), 596-606. 